\title{
I $_{B}$ W DI KAWASAN GREENBELT KECAMATAN SUKASADA KABUPATEN BULELENG
}

\author{
Oleh, \\ Ida Bagus Putu Mardana \\ Jurusan Pendidikan Fisika \\ Fakultas Matematika dan Ilmu Pengetahuan Alam \\ Universitas Pendidikan Ganesha
}

\begin{abstract}
ABSTRAK
Kawasan greenbelt merupakan wilayah konservasi air dan vegetasi hijau (greenbelt zone) yang membentang dari dataran rendah ke perbukitan bedugul berpotensi bagi pengembangan wisata desa, agrowisata, kerajinan kreatif-inovatif, pertanian dan peternakan sebagai sumber kehidupan masyarakat di kecamatan Sukasada. Kawasan ini masih bergulat dengan masalah kemiskinan, eksklusivitas-wisata, angka pengangguran, buta aksara, putus sekolah, rawan bencana, konflik sosio-ekonomi-politik, derajat kesehatan dan pendidikan masyarakat yang rendah bagi kabupaten Buleleng. Kondisi faktual masyarakat di kawasan ini, mendorong Undiksha bekerjasama dengan Unipas dan Pemkab Buleleng untuk melaksanakan kegiatan IbW. Kegiatan IbW kawasan greenbelt di kecamatan Sukasada kabupaten Buleleng Provinsi Bali, menyasar pada 4(tempat) desa, yakni desa Ambengan, desa Gitgit, desa Wanagiri, dan desa Pancasari bertujuan untuk melakukan pemetaan aset wilayah dan pemberdayaan masyarakat dalam melaksanakan program ipteks peningkatan pengetahuan dan keterampilan dalam pertanian-peternakan-perikanan, pendidikan life skill, kewirausahaan, pembinaan adatistiadat, keagamaan, lembaga sosial, sanitasi, dan kepariwisataan. Metode pelaksanaan $\mathrm{I}_{\mathrm{B}} \mathrm{W}$ dalam pemberdayaan masyarakat menggunakan pendekatan SLA (Sustainable Livelihoods Approach), yang bersendikan pada 3(tiga) tahapan kegiatan, yakni (1) tahap penyadaran (Awareness), (2) tahap pengkapasitasan/pendampingan (capaciting /scaffolding), dan (3) tahapan pelembagaan (institutionalization). Kegiatan IbW pada tahun menghasilkan luaran : (1) Rencana strategis (Renstra) dan pemetaan wilayah, (2) terwujudnya sentra pengolahan kelapa Terwujudnya demplot peternakan-pertanian ramah lingkungan (zero waste), (3) terwujudnya produk wisata rural-agrotourism culture, dan (4) publikasi ilmiah hasil program IbW pada jurnal lokal, nasional, dan internasional.
\end{abstract}

Kata-kata kunci: pemberdayaan masyarakat, kawasan greenbelt, SLA, potensi wilayah, Ipteks bagi Wilayah (IbW)

\section{Pendahuluan}

Kabupaten Buleleng terletak dibagian utara Pulau Bali memnjang kebarat dan ketimur. secara geografis Kabupaten Buleleng terletak pada posisi $8^{0} 03^{\prime} 40^{\prime \prime}-8^{0} 23^{\prime} 00^{\prime \prime}$ 
lintang selatan dan $114^{0} \quad 25^{\prime} 55^{\prime \prime}-\quad 115^{0} \quad 27^{\prime} 28^{\prime \prime}$ bujur timur Kabupaten Buleleng memiliki pantai dibagian utara yang panjangnya 157,05 km. Secara luas wilayah, Kabupaten Buleleng adalah 136.588 hektar atau 24,25\% dari Luas Provinsi Bali. Kabupaten Buleleng memiliki batas-batas wilayah seperti ditunjukkan pada gambar 1A: Utara: Laut Bali, Timur : Kabupaten Karangasem, Selatan:Kabupaten Jemberana, Kabupaten Tabanan, Kabupaten Badung, Kabupaten Bangli , Barat : Selat Bali. Wilayah kecamatan Sukasada sebagai wilayah $\mathrm{I}_{\mathrm{B}} \mathrm{W}$, dengan luas Wilayah 172,93 $\mathrm{km}^{2}$, mempunyai batas-batas seperti ditunjukkan pada gambar 1(B): Utara: Laut Bali, Timur: Kecamatan Sawan/Kubutambahan, Selatan : Kabupaten Badung/Tabanan, Barat $\quad$ : Kabupaten Banjar/Busungbiu

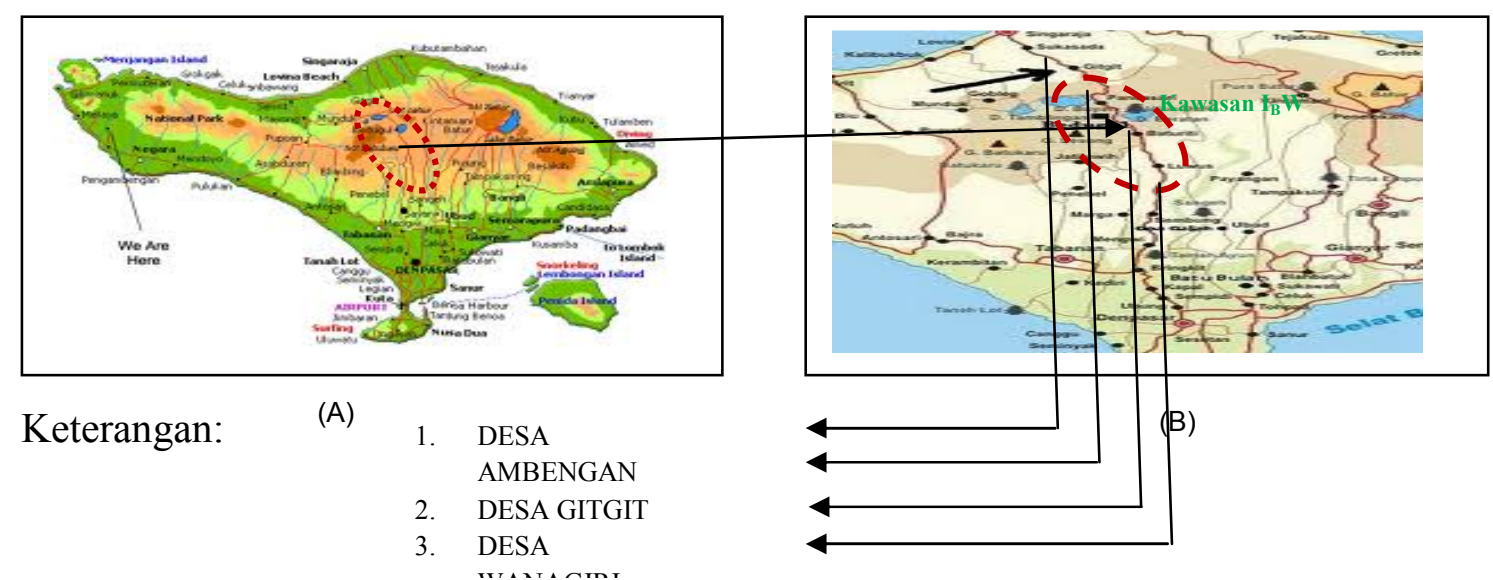

Gambar 1. Lokasi dan Batas $\mathrm{I}_{\mathrm{B}} \mathrm{W}$

Kecamatan Sukasada terletak di Kabupaten Buleleng, Provinsi Bali yang terdiri dari 15 Desa, dengan luas wilayah 172,93 km. jumlah penduduk 71.459 jiwa. Kecamatan Sukasada merupakan daerah hutan, perkebunan serta pertanian. Kecamatan ini terletak di sebelah utara pulau Bali. Keadaan tanahnya sebagian besar hutan dan tegalan yang hanya dapat ditanami tanaman hortkultura, palawija, perkebunan, dan vegetasi hutan, beberapa diantaranya persawahan. Penggunaan lahan di kecamatan Sukasada adalah sebagai berikut: (1) lahan sawah 1943 ha, (2) lahan tegalan : 4543 ha; (3) lahan perkebunan 5846 ha; (4) pekarangan: 507 ha; (5) hutan 2966 ha; (6) tanah negara 27.135 ha; lain-lain 318.61 ha. Kecamatan Sukasada beriklim tropis dengan curah hujan rata-rata $1651 \mathrm{~mm}$ dan hari hujan 65 hari (Buku Pola Pengembangan 
Wilayah Kecamatan (PPWK) Kecamatan Sukasada, kabupaten Buleleng, tahun 2011). Iptek bagi wilayah $\left(\mathrm{I}_{\mathrm{B}} \mathrm{W}\right)$ di kecamatan Sukasada akan meliputi kawasan 4(empat) desa yang saling berdekatan, yaitu: desa Pancasari, desa Wanagiri, desa Gitgit, dan desa Ambengan, seperti ditunjukkan pada gambar 1(B). Empat desa ini mempunyai batas wilayah utara (Laut Bali), Timur (kecamatan Sawan), Barat (kecamatan Banjar), Selatan (kabupaten Tabanan).

Berdasarkan RTRW kabupaten Buleleng 2004-2012 dan pola pengembangan wilayah kecamatan Sukasada, kecamatan Sukasada dibagi menjadi 4 wilayah, yaitu (1) wilayah pengembangan kawasan wisata desa, wisata desa, dan hutan lindung, yakni desa Pancasari, Wanagiri, Kayu putih, Gitgit, Selat dan Tegalinggah; (2) wilayah pengembangan ibu kota kecamatan, yakni desa Sukasada, Panji , desa Sambangan; dan (3) Wilayah pengembangan industri pertanian dan kerajinan, yakni desa Ambengan, Bulian, dan Panji Anom, (4) Wilayah penyangga, yakni desa Pegayaman, Silangjana, Pegadungan. Wilayah yang dipilih untuk program IbW sesuai dengan pemikiran kritis pengusul, Bappeda buleleng, dan tokoh-tokoh masyarakat di kecamatan Sukasada adalah wilayah pengembangan kawasan wisata dan hutan lindung, karena kawasan ini merupakan greenbelt zone yang sangat strategis dan memegang peranan penting bagi pengembangan wisata desa, agrowisata, kerajinan kreatif-inovatif, pertanian dan peternakan sebagai sumber kehidupan masyarakat. Jadi desa-desa yang dilibatkan dalam program IbW ini adalah desa Pancasari, desa Wanagiri, desa Gitgit, dan desa Ambengan. Keempat desa-desa sasaran $\mathrm{I}_{\mathrm{B}} \mathrm{W}$ merupakan kawasan yang sangat vital, karena kawasan ini akan dipersiapkan sebagai kawasan wisata dan konservasi hutan di kecamatan Sukasada (RTRW Buleleng 2004-2014). Walupun terletak pada posisi yang vital dan strategis (trans Bali utara-Jawa), ternyata empat desa ini menyumbangkan jumlah angka kemiskinan, kebodohan, angka pengangguran, buta aksara, putus sekolah, rawan bencana yang cukup besar, derajat kesehatan masyarakat yang rendah bagi kabupaten Buleleng, dan kualitas pendidikan yang rendah, yang nampaknya perlu mendapat penanganan segera dalam upaya mewujudkan kawasan desa wisata mandiri (Rencana Strategis Kecamatan Sukasada, 2008-2013).

Secara umum, kondisi eksisting kawasan $\mathrm{I}_{\mathrm{B}} \mathrm{W}$ yang meliputi desa Pancasari, desa Wanagiri, desa Gitgit, dan desa Anbengan merupakan kawasan yang diproyeksikan 
menjadi zonasi wisata, sumber air, pertanian, perkebuanan, peternakan dan konservasi hutan (PKWK, 2007), sehingga pada kawasan ini dicanangkan berbagai fasilitas wisata dan konservasi hutan, yang didukung aktivitas pertanian, peternakan dan industri kerajinan kreatif terpadu sebagai penyangga aktivitas pengembangan kawasan hutan (Green belt), kawasan pariwisata, dan kawasan industri pertanian dalam arti luas. Di kawasan ini juga diperuntukan sebagai areal konservasi hutan, pertanian dan peternakan, wisata untuk menunjang ekonomi masyarakat, sekaligus sebagai pusat pengembangan industri pariwisata yang dapat mengintegrasikan aktivitas masyarakat pedesaan, pertanian, peternakan dan keindahan potensi alam. Secara umum, kecamatan Sukasada merupakan kecamatan dengan heterogenitas penduduk yang sangat variatif berjumlah 71.459 orang terdiri dari 35.905 penduduk perempuan dan 35.554 penduduk laki-laki. Dengan balutan budaya dan kearifan lokal, seperti, menyama-braya, gotongroyong, nyama bali-nyama selam, nyama kristen dan nyama china masyarakat di wilayah Sukasada dapat hidup berdampingan secara harmonis.

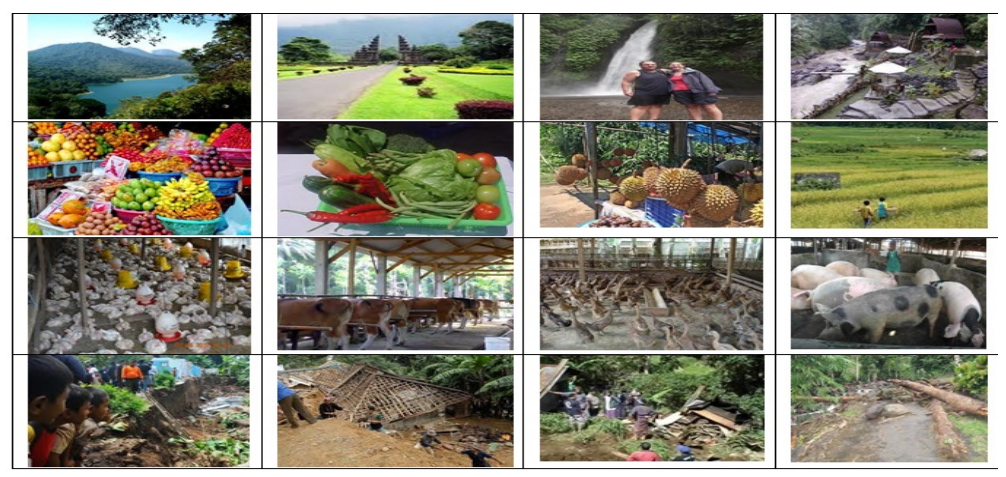

Gambar 2. Potensi Wilayah IbW di kecamatan Sukasada

Keempat desa ini merupakan wilayah perbukitan dan pegunungan, yakni beriklim tropis, dengan curah hujan yang relative cukup tinggi. Keadaan tanahnya sebagian besar subur dan basah yang ditanami vegetasi hutan, tanaman hortikultura, palawija, perkebunan, dan persawahan. Lapisan top soil tanah relatif tebal dengan tingkat kesuburan yang tinggi (BPPT, 2010). Pada musim hujan, maupun musim kemarau wilayah keempat desa ini nampak subur dan menghijau, sehingga perbukitan dan pegunungan ini merupakan bagian dari kawasan Green-belt yang memisahkan bagian utara dan selatan pulau Bali. 
Kondisi SDM penduduk wilayah IbW mengacu pada profil kecamatan dan potensi desa (Monographi desa, 2008) banyak pendudukan yang tidak bersekolah, dan warga yang menamatkan pendidikan SMP, dan SMA dalam jumlah yang relatif kecil, hanya sebagian kecil dari jumlah penduduk yang bisa menamatkan pendidikan tinggi. Hal ini menunjukkan adanya kesenjangan pendidikan yang sangat tajam. Sebagian besar pancaharian penduduk sebagai petani sekaligus peternak (65\%), 15\% PNS, dan 5\% wiraswasta/pedagang, $5 \%$ pelayan, dan sisanya $10 \%$ pengganguran. Pada musim hujan, penduduk berkonsentrasi pada pemenuhan kebutuhan sehari-hari melalui pertanian, dan peternakan. Budidaya pertanian dan peternakan masih bersifat tradisional, yang miskin dengan sentuhan ipteks.

Di samping itu, kurangnya kesadaran penduduk dalam kesehatan dan sanitasi lingkungan, serta rendahnya daya dukung dan pelayanan lembaga kesehatan, menyebabkan wilayah kecamatan Sukasada ini sangat rentan terhadap wabah penyakit baik di musim hujan maupun di musim kemarau. Pengembangan peternakan tradisional yang tidak ramah lingkungan, sering menimbukan persoalan sanitasi lingkungan dan sumber wabah penyakit. Padahal limbah pertanian dan peternakan, melalui penerapan ipteks dapat dirubah menjadi sumber pakan ternak, pupuk organik dan sumber energi bakar alternatif sehingga dapat meningkatkan kualitas hidup dan kemandirian masyarakat. Posyandu yang ada masih ditangani secara linier dan mekanistik dengan kebergantungan tinggi dengan program kesehatan kabupaten.

Dengan daya dukung luas wilayah yang cukup memadai dan panorama alam yang indah, dengan kuantitas jumlah petani dan peternak yang cukup signifikan, wilayah kecamatan ini sangat berpotensi untuk jadi zona wisata desa, sentra pertanian/peternakan yang bisa memenuhi kebutuhan pangan dan meningkatkan kondisi ekonomi masyarakat menuju wilayah desa-desa wisata yang mandiri pangan-energi. Sebenarnya upaya-upaya peningkatan aktivitas wisata dan produksi pertanian dan peternakan sudah dilakukan, melalui program sadar wisata dan penelitian dan pendapingan dari BPPT Propinsi Bali (Laporan BBPPT provinsi Bali, 2007) dalam program Primatani, namun nilai ekonomi sektor pariwisata dan produksi pertanian, peternakan dan perikanan masih relatif sangat kecil, sehingga belum mampu mendongkrak kualitas hidup masyarakat. Hal ini disebabkan (1) kurangnya pengetahuan 
dan keterampilan masyarakat dalam peningkatan nilai ekonomis produk wisata, (2) rendahnya intensitas masyarakat yang bergerak dalam bidang wirausaha/perdagangan, kurangnya diversifikasi produk wisata yang masih tersegmentasi dengan pertanian/peternakan, dan budaya masyarakat, (3) sistem mekanisme pasar yang belum berpihak pada masyarakat desa, serta (4) tingginya potensi bencana longsor yang selalu mengancam runtuhnya pilar-pilar sosio-ekonomi, keamanan dan kenyamanan hidup masyarakat.

Persoalan utama yang menjadi prioritas Pemerintah kabupaten Buleleng di kawasan Greenbelt di kecamatan Sukasada, khususnya di desa Ambengan, Gitgit, Wanagiri dan Pancasari adalah (1) masalah bencana longsor yang selalu terjadi setiap tahun dan memakan korban jiwa, (2) aktivitas pertanian-peternakan yan belum mampu mendongkrak ekonomi masyarakat, (3) masalah pendidikan terkait banyaknya segmen masyarakat yang buta-aksara, pengangguran, dan putus sekolah; (4) masalah sosioekonomi, dimana masih banyak komunitas di kawasan ini masih berada di bawah garis kemiskinan; (5) masalah kepariwisataan, yang dengan upaya mengantarkan kawasan menjadi rural-agrotorurism culture; (4) masalah kesehatan dan sanitasi lingkungan, dan (5) persoalan konflik sosial vertikal-horizontal karena perebutan hegemoni adat, ruang, religi, dan sosio-ekonomi-politik, dan potensi penyebaran virus HIV/AIDS. Pemerintah kabupaten Buleleng, melalui dinas terkait telah melakukan berbagai upaya dalam menanggulangi masalah kesehatan, kemiskinan, pendidikan, pertanian-peternakanperikanan, kepariwisataan, potensi penyebaran HIV/AIDS, dan sosio-ekonomi-politik di Desa Ambengan, Gitgit, Wanagiri dan Pancasari. Akan tetapi, di dalam pelaksanaanya berbagi upaya yang telah dilakukan tersebut belum membuahkan hasil yang optimal, karena kurangnya intesitas keterlibatan masyarakat dalam program pembangunan yang dicanangkan pemerintah.

Berdasarkan uraian potensi dan propek wilayah 4 desa, yakni desa Ambengan, Gitgit, Wanagiri, dan Pancasarit di kecamatan Sukasada dapat dirumuskan permasalahan utama yang potensial untuk dipecahkan, baik yang berhasil diidentifikasi melalui survey awal pengusul, wawancara intensif dengan tokoh masyarakat, pejabat permerintahan kecamatan/desa maupun permasalahan aspek sosial ekonomi dalam 
RPJMD desa Ambengan, desa Gitgit, desa Wanagiri, dan desa Pancasari adalah sebagai berikut.

(1) Rendahnya kesadaran, pengetahuan, keterampilan, dan keterlibatan elemen masyarakat dalam praksis kepariwisataan secara holistik berbasis pada wisata alam, budaya masyarakat, dan pertanian/peternakan. Pariwisata yang hanya tersegmentasi dan terbelenggu pada keindahan panorama alam kurang dapat mengagetasi dinamika aktivitas sosio-ekonomi masyarakat menuju peningkatan kualitas hidup dan kenyamanan masyarakat, (2) Rendahnya budaya kerja dan produktivitas ekonomi masyarakat menyebabkan rendahnya pendapatan perkapita dan pendapatan keluarga. Pedahal potensi alam dan dukungan program dan komitmen pemerintah dan institusi lain relatif cukup tinggi. Selain itu, belum terberdayanya lembaga-lembaga ekonomi masyarakat, UKM dan industri kerajinan kreatif-inovatif rumah tangga karena terbatasnya akses kepada sumber daya produktif, terutama permodalan, pasar, dan informasi dan teknologi, dan tumbuh suburnya rentenir telah mengurangi dinamika ekonomi masyarakat, (3) Masih rendahnya kualitas kesehatan masyarakat, kondisi kesehatan lingkungan, terutama yang menyangkut sanitasi dasar, dan perilaku masyarakat yang kurang mendukung pola hidup bersih dan sehat telah memberi kontribusi pada rendahnya status penduduk miskin dan kesehatan masyarakat. Peluang terjangkitnya penyakit demam berdarah dan penyakit endemik lainnya di wilayah Wanagiri, Ambengan, Gitgit sangat tinggi, karena aktivitas produktif masyarakat tidak ramah lingkungan, (4) Dari sisi kewilayahan, desa Ambengan, desa Gitgit, desa Wanagiri, dan desa Pancasari merupakan daerah pegunungan konservasi hutan yang sangat berpotansi terjadinya rawan bencana longsor setiap tahun. Kepedulian masyarakat dalam menjaga kelestarian konservasi hutas di kawasan Greenbelt relative masih kurang, terbukti intensitas perambasan hutan masih tinggi, yang berpotensi mendatangkan malapetaka longsor. Di sisi yang lain, rendahnya budaya dan kemampuan masyarakat dalam mekanisme mitigasi bencana alam sering meimbulkan kerusakan pada simpul-simpul produktivitas sosio-ekonomi masyarakat, yang berujung pada keterpurukan kualitas dan kenyamanan hidup masyarakat, (5) Masih rendahnya akses masyarakat terhadap pendidikan yang berkualitas, kurangnya pemerataan pendidikan dan penyediaan tenaga terampil, menyebabkan terjadinya kesenjangan 
pendidikan yang cukup tajam. Penyebab utama yang teridentifikasi berkontribusi pada rendahnya kualitas pendidikan di wilayah kecamatan Sukasada ini adalah (a) ketersediaan tenaga pendidik yang belum memadai baik secara kuantitatif maupun kualitatif, (b) fasilitas belajar belum tersedia secara mencukupi, (c) biaya operasional pendidikan belum disediakan secara memadai, (d) kekurangan tenaga pendidik, (e) ekonomi masyarakat yang rendah, dan (e) faktor geografis dan budaya masyarakat, dan (6) Minimnya terapan teknologi tepat guna di masyarakat dalam pengolahan hasil pertanian, peternakan, dan perikanan yang dapat mengantarkan desa-desa di kawasan ini sebagai desa mandiri pangan dan energi. Budi daya pariwisata, pertanian, peternakan, dan perikanan yang ada saat ini masih bersifat tradisional, monokultur, dengan pengagarapan yang parsial, dan kurang profesional yang dapat meningkatkan ketahanan pangan masyarakat dan berpotensi untuk menumbuhkembangkan dinamika perekonomian masyarakat. (RPJMD dan Renstrades,2008-2013).

\section{Metode Pelaksanaan Pengabdian}

Berdasarkan paparan potensi-potensi daerah, kearifan lokal dan permasalahan yang dimiliki desa-desa dalam cakupan wilayah $\mathrm{I}_{\mathrm{B}} \mathrm{W}$ maka perlu disusun strategi sebagai solusi pemecahan masalah dalam mewujudkan desa mandiri dengan mensinergiskan potensi masyarakat, yaitu SDM produktif, kelompok pariwisata, kelompok petani, kelompok ternak, kelompok nelayan, kelompok pengerajin, berbagai organisasi adat, lembaga ekonomi masyarakat, koperasi, arisan, dan Bank, industri kecil, UKM), dan optimalisasi pemanfaatan lahan dan potensi alam yang luas dan beragam (areal pariwisata, pertanian lahan kering/basah, peternakan, perikanan laut/tawar, kehutanan). Potensi unggulan pokok yang menjadi prioritas penerapan program ipteks dalam program IbW ini adalah (1) potensi pariwisata yang diarahkan pada pengembangan rural-agrotourism culture yang didukung oleh fanorama alam, pertanian, peternakan, dan perikanan (1) potensi pertanian dalam arti luas, (2) potensi peternakan yang ramah lingkungan, (3) perikanan dengan perbaikan segmen jejaring pasar, (4) pendidikan kelompok kelas kecil dan kesehatan terpadu berbasis desa adat/masyarakat, (5) UKM/Industri rumah tangga dan lembaga ekonomi masyarakat, (6) industri kerajinan handycraft dan diversifikasi produk kreatif olahan hasil pertanian, peternakan, dan 
perikanan, dan (7) program reboisasasi dengan vegetasi lokal tradisional Bali dan mitigasi bencana alam.

Solusi yang ditawarkan untuk menangani permasalahan wilayah yang meliputi 4 desa sasaran $\mathrm{I}_{\mathrm{B}} \mathrm{W}$ adalah melaksanakan program ipteks bagi wilayah dengan rincian sebagai berikut: (1) Melakukan pemetaan potensi-potensi unggul di wilayah $\mathrm{I}_{\mathrm{B}} \mathrm{W}$, kearifan lokal, dan pemetaan wilayah sesuai dengan peruntukan dan kondisi fisik dan daya dukung lingkungan. Selanjutnya melakukan evaluasi diri dan penyusunan rancana program strategis, dan perancanangan aktivitas-aktivitas inisiasi $\mathrm{I}_{\mathrm{B}} \mathrm{W}$ berdasarkan potensi-potensi unggul yang dimiliki sebagai penjabaran program-program strategis yang dicanangkan, dan (2) Melaksanakan program aksi ipteks dalam penanganan masalah di wilayah $\mathrm{I}_{\mathrm{B}} \mathrm{W}$, yakni: (i) Program ipteks peningkatan kepariwisataan yang mengarah pada rural-agrowisata culture sebagai pengintegrasian dinamika pariwisata, pertanian, peternakan, dan budaya lokal masyarakat, (ii) Program ipteks peningkatan pengetahuan dan keterampilan dalam desain, diversifikasi produk, (iii) managemen, dan pemasaran seni kerajinan tangan melalui pendidikan, pelatihan dan pendampingan, Program ipteks peningkatan pengetahuan dan keterampilan dalam diversifikasi produk pengolahan kelapa menjadi produk berorientasi pasar melalui pengembangan demplot sentra industri kecil berbasis kelapa, (iv) Program ipteks peningkatan pengetahuan dan keterampilan managemen wirausaha, perkoperasian dan pemberdayaan ekonomi masyarakat dan revitalisasi UKM-UKM berbasis kearifan lokal melalui pendidikan, pelatihan dan pendampingan, (v) Program ipteks peningkatan pengetahuan dan keterampilan pengolahan aneka makanan tradisional dan modern berbasis hasil pertanian, perkebunan, dan perikanan melalui pendidikan, pelatihan dan pendampingan produksi, managemen, dan pemasaran, (vi) Program ipteks peningkatan pengetahuan dan keterampilan dalam program pertanian terpadu melalui demplot pertanian multikultur, pengolahan pupuk organik, dan pakan ternak dari limbah hasil pertanian, dalam rangka meningkatkan ketahanan pangan masyarakat dan ketahanan pakan ternak, (vii) Program peternakan melalui demplot peternakan terpadu yang ramah lingkungan (zero waste), pengolahan limbah ternak menjadi pupuk organik dan energi bakar biogas sebagai bagian integral dari upaya penyediaan energi alternatif bagi masyarakat baik di musim hujan maupun musim kemarau, (viii) Program ipteks pendidikan kontekstual 
untuk meningkatkan kualitas pendidikan/pengurangan pengangguran,dan pemberantasan buta huruf/putus sekolah melalui pendidikan life skill dan model pendidikan kelas kecil (small group learning) berbasis kearifan lokal, (ix) Program ipteks untuk pembinaan kesehatan keluarga dan masyarakat, melalui model posyandu berbasis desa pekraman dan revitalisasi pelayanan kesehatan Puskesmas, (x) Program ipteks mitigasi bencana longsor dan konservasi hutan di daerah perbukitan di sekitar kawasan greenbelt di desa-desa wilayah $\mathrm{I}_{\mathrm{B}} \mathrm{W}$ dengan item vegetasi local tradisional Bali, (xi) Melakukan evaluasi dan refleksi komprehensif terhadap program aksi, sebagai dasar pertimbangan dalam program pendampingan/ pemantauan demi menjaga sustainabilitas program $\mathrm{I}_{\mathrm{B}} \mathrm{W}$ di wilayah Sukasada secara mandiri.

Metode yang akan digunakan untuk pelaksanaan $\mathrm{I}_{\mathrm{B}} \mathrm{W}$ adalah metode SLA (Sustainable Livelihoods Approach). Pemberdayaan masyarakat dengan the Sustainable Livelihoods Approach (SLA) pada dasarnya upaya pelibatan (partisipasi) masyarakat untuk belajar dan beraktivitas secara berkelanjutan dengan cara unik mereka menjalani hidup dalam rangka meningkatkan kualitas hidup mereka. Menurut Ellis (1998), the sustainable livelihoods approach (SLA) is the process by which rural families construct a diverse portfolio of activities and social support capabilities in their struggle for survival and in order to improve their standards of livings. Hal ini didukung oleh Olivier Serrat (2008), yang menyatakan bahwa " The sustainable livelihoods approach is a way of thinking about the objectives, scope, and priorities for development activities. It is based on evolving thinking about the way the poor and vulnerable live their lives and the importance of policies and institutions.

Kodisi exciting masyarakat di wilayah $\mathrm{IbW}$, yang bertautan dengan potensi wilayah, SDA, SDM, dan kearifan-kearifan lokal masyarakat dijadikan starting point dalam memetakan program-program pemberdayaan masyarakat, yang sudah tentu melibatkan usulan dan tuntutan kebutuhan masyarakat dari bawah (internal) dan mensinergiskan dengan program-proram kebijakan pemerintah daerah yang muncul dari analisis kritis Undikasha, Unipas dan Pemkab Buleleng (eksternal) sehingga dapat dirumuskan proram-program aksi yang dapat mengantarkan masyarakat pada kondisi expeting yang diinginkan dan disepakati bersama. Program aksi pemberdayaan masyarakat yang menempatkan masyarakat secara aktif berpartisipasi dalam 
perencanaan, pelaksanaan, monitoring, dan evaluasi melalui proses pembelajaran dan pendampingan akan dapat meningkatan intensitas partisipasi, self-belonging, dan responsibility sehingga dapat menjamin dukungan material, finansial, dan pemikiran tepat sasaran dalam pemberdayaan masyarakat untuk mengantarkan masyarakat hidup lebih mandiri, aman, sejahtera, sehat dan harmonis.

\section{Hasil dan Pembahasan}

Kegiatan IbW di kawasan Greenbelt Sukasada tahun 2013, diawali dengan sosialisasi secara vertikal dengan menghaturkan upacara permohonan ijin/permakluman (piuning) kehadapan Tuhan Yang Maha Esa yang berstana di Pura Desa masing-masing di desa Pancasari, Wanagiri, Gitgit dan Ambengan. Selanjutnya, sosialisasi juga dilakukan secara horizontal dengan masyarakat yang menghadirkan aparat pemerintah di tingkat kecamatan, desa, adat, tokoh masyarakat dan ketua kelompok produktifekonomis masyarakat di kawasan Greenbelt Sukasada.

Pendataan potensi wilayah di desa Pancasari, desa Wanagiri, desa Gitgit, dan desa Ambengan difokuskan pada pendataan aset yang dimiliki masyarakat, baik secara personal dalam keluarga, maupun aset secara komunal dalam kelompok tani-ternak, yang berpotensi untuk diberdayakan sehingga dapat meningkatkan pendapatan masyarakat. Hasil survey, observasi dan wawancara yang mendalam dalam diperoleh profil aset masyarakat seperti ditunjukkan pada tabel 1 .

Tabel 1. Profil Potensi Wilayah

\begin{tabular}{|l|l|l|l|c|c|}
\hline $\begin{array}{l}\text { N } \\
\mathbf{0}\end{array}$ & Potensi Wilayah & $\begin{array}{l}\text { Desa } \\
\text { Pancasari }\end{array}$ & $\begin{array}{l}\text { Desa } \\
\text { Wanagiri }\end{array}$ & $\begin{array}{l}\text { Desa } \\
\text { Gitgit }\end{array}$ & $\begin{array}{l}\text { Desa } \\
\text { Ambengan }\end{array}$ \\
\hline 1 & Luas Area(ha) & 3536 & 20200 & 1900 & 558 \\
\hline & Sawah & 522 & 2120 & 25 & 24 \\
\hline & Pekarangan & 68 & 24 & 76 & 30 \\
\hline & Tegalan & 593 & 600 & 657 & 54 \\
\hline & Perkebunan & 117 & 90 & 119 & 73 \\
\hline & Belum digarap/hutan & 2321 & 130 & 1200 & 123 \\
\hline 2 & Kualitas SDM & & & & \\
\hline & SD & 3502 & 104 & 2829 & 394 \\
\hline & SMP & 1254 & 227 & 337 & 20 \\
\hline & SMA & 565 & 83 & 253 & 10 \\
\hline & Sarjana & 248 & 17 & 43 & 15 \\
\hline 3 & Mata Pencaharian & & & & \\
\hline
\end{tabular}




\begin{tabular}{|l|l|c|c|c|c|}
\hline & Petani (or) & 5116 & 1794 & 2522 & 1936 \\
\hline & Peternakan/Perikanan & 167 & 345 & 150 & 231 \\
\hline & PNS/TNI/POLRI & 182 & 219 & 108 & 80 \\
\hline & Swasta & 495 & 943 & 667 & 275 \\
\hline $\begin{array}{l}\text { Penganggur/tidak } \\
\text { bekerja/pencari kerja }\end{array}$ & 205 & 436 & 387 & 543 \\
\hline 4 & $\begin{array}{l}\text { Potensi } \\
\text { Pertanian(ha) }\end{array}$ & & & & \\
\hline & Kelapa & 568 & 478 & 593 & 380 \\
\hline & Jagung & 46 & 78 & 18 & 100 \\
\hline & Mangga & 78 & 100 & 105 & 56 \\
\hline & Padi & 30 & 1640 & 107 & 21 \\
\hline & Pisang & 314 & 56 & 244 & 78 \\
\hline & Palawija & 219 & 33 & 231 & 26 \\
\hline 5 & $\begin{array}{l}\text { Potensi Peternakan } \\
\text { (ekor) }\end{array}$ & & & & \\
\hline & Sapi & 3685 & 363 & & 1.800 \\
\hline & Babi & 6505 & 721 & & 2.500 \\
\hline & Kambing & 964 & 87 & & 853 \\
\hline & Ayam & 14.425 & 7945 & & 21.500 \\
\hline
\end{tabular}

Program ipteks peningkatan pengetahuan dan keterampilan dalam diversifikasi produk pengolahan kelapa menjadi produk berorientasi pasar dilakukan dengan pengembangan demplot sentra industri kecil berbasis kelapa. Pada kegiatan $\mathrm{IbW}$ tahun pertama, pengelolaan demplot pengolahan kelapa ini ditangani oleh Ibu-ibu rumah tangga yang terkabung dalam Kelompok Wanita Tani (KWT) di desa Ambengan. Pada demplot yang ada di desa Ambengan dibantu hibah IbW berupa peralatan mesin pengolah daging kelapa "three in one", yakni parut, peras, dan saring, yang diproduksi oleh unit "UJI" Universitas Mahasaraswati Denpasar. Aktivitas produktif ekonomi berbasis kelapa dicanangkan menjadi aktivitas unggulan poktan dalam menghasilkan generate revenue bagi masyarakat baik secara personal maupun kelompok.

Dengan bantuan IPTEKS, tanaman kelapa dapat ditingkatkan pemanfaatannya baik dari segi pemanfaatan langsung, dikonsumsi atau diolah menjadi minyak goreng, batangnya untuk bangunan rumah/mobiler, bahan bakar untuk industri kapur, genteng serta gerabah, maupun dari segi pengolahan dengan sentuhan teknologi modern untuk menghasilkan produk-produk berorientasi ekspor. Secara utuh buah kelapa terdiri dari (1) bagian luar, adalah sabut kelapa dan tempurung kelapa, (2) daging kelapa, dan (3) air kelapa. Sabut kelapa dapat dipilah menjadi dua komponen yaitu serabut dan serbuk 
(cocodust). Tempurung kelapa digunakan sebagai arang dan untuk bahan bakar produksi tanah liat. Dengan cara yang lebih modern tempurung kelapa dapat diolah menjadi briket sebagai bahan bakar untuk memaksa, menjadi karbon hita dan karbon aktif, sedangkan asap pembakaran tempurung kelapa dapat diolah menjadi liquid smoke sebagai bahan pengawet ikan.

Pelatihan pengolahan kelapa menjadi produk VCO dilaksanakan pada 4 Oktober 2013 bertempat di desa Ambengan. Tahapan-tahapan pengolahan VCO yang disampaikan pada Kelompok Wanita Tani (KWT) dan masyarakat sekitar seperti uraian berikut ini.

(1) Penyiapan Bahan Baku, Buah kelapa yang akan diolah menjadi VCO adalah buah yang tua, yakni berumur 11-12 bulan, yang ditandai dengan kulit sabut berwarna coklat. Buah kelapa tua akan menghasilkan rendemen minyak yang tinggi; (2) Pembuatan Santan: Buah kelapa tua dikupas kemudian dibelah dan dagingnya dikeluarkan dari tempurung. Daging buah kelapa lalu diparut secara manual atau digiling menggunakan mesin. Hancuran daging buah lalu ditambah air dengan perbandingan 1:2. Selanjutnya, ekstrak dipres dengan mesin pengepres atau secara manual kemudian disaring sehingga diperoleh santan. Dari 30 butir kelapa (rata-rata bobot daging buah 400 g/butir) diperoleh 30 liter santan. (3) Pemisahan Krim: Santan yang diperoleh dituang pada ember plastik transparan, kemudian didiamkan 2 jam. Selama pendiaman, santan akan terbagi menjadi tiga lapisan, yaitu lapisan atas berupa krim (kaya minyak), lapisan tengah berbentuk skim (kaya protein), dan lapisan bawah berupa endapan. Krim dipisahkan dan digunakan sebagai bahan baku VCO. (4) Pembuatan Starter Ragi Tape Pengolahan VCO menggunakan ragi tape diawali dengan membuat cairan starter ragi tape. Caranya, skim kelapa $450 \mathrm{ml}$ dicampur dengan air kelapa $50 \mathrm{ml}$, kemudian ditambahkan ragi tape $2 \mathrm{~g}$, diaduk sampai homogen, lalu didiamkan (difermentasi) pada suhu ruang selama 12 jam.

Penambahan air kelapa bertujuan untuk memperkaya nilai gizi media untuk proses perbanyakan ragi tape; (5) Pencampuran Krim dengan Starter Ragi Tape: Krim yang diperoleh, sekitar 12 liter, dibagi tiga bagian (masing-masing 4 liter), kemudian dicampur dengan starter ragi tape masing masing 10\%, 20\%, dan 30\%. Sebagai contoh, jika menggunakan starter tape 10\% maka untuk krim 4 liter ditambahkan starter ragi 
tape $400 \mathrm{ml}$. Campuran diaduk homogen kemudian dituang pada wadah transparan dan didiamkan 8-10 jam. Selama proses pendiaman, campuran akan terpisah menjadi tiga lapisan, yaitu minyak (lapisan atas), blondo berwarna putih (lapisan tengah), dan air (lapisan bawah). Selanjutnya, minyak dipisahkan dari blondo dan air. Alur proses pengolahan VCO disajikan pada Gambar 2, dan (6) Penyaringan Minyak: Minyak yang diperoleh disaring menggunakan zeolit, yaitu sejenis batuan yang di samping berfungsi menyaring juga menyerap bau yang kurang enak dan menurunkan kadar air. Produk yang diperoleh dari penyaringan adalah VCO.

Partisipasi anggota Kelompok Wanita Tani (KWT) dan anggota poktan dalam kegiatan usaha produktif pengolahan kelapa sangat tinggi, hal ini dapat dilihat dari intensitas kehadiran, dan kuantitas dan kualitas persoalan/pertanyaan yang disampaikan terkait dengan pembuatan minyak kelapa VCO dan minyak lentik/minyak tradisional. Hasil pemberdayaan poktan dalam usaha produktif berbasis kelapa adalah (1) adanya peningkatan kompetensi dalam pengolahan kelapa, khususnya dari minyak tradisional menjadi VCO, (2) menghasilkan kualitas produk minyak tradisional/VCO yang lebih baik, (3) meningkatkan kapasitas produksi pengolahan kelapa menjadi minyak/VCO, (4) mendorong proses transformasi IPTEKS dalam penggunaan peralatan mesin pengolahan kelapa "three in one"bantuan IbW kepada kelompok poktak, dan (5) usaha produktif berbasis kelapa ini akan mendorong kelompok untuk membentuk koperasi usaha kelapa yang menjadi unggulan komoditas ekonomi desa di wilayah garapan IbW Greenbelt Sukasada

Keterbatasan pengetahuan dan ipteks di kawsasan ini, pola usahatani yang dikembangkan bersifat subsistem (tradisional). Pola usahatani tanaman semusim yang biasanya dilakukan di kawasan ini adalah pola usahatani tanaman pangan seperti jagung, kacang tanah dan jenis palawija lainnya. Pola usahatani tanaman pangan dilakukan pada musim penghujan menggunakan teknologi sederhana dengan varietas lokal sehingga hasilnya rendah. Selain itu pemeliharaan ternak (umumnya sapi) masih tradisional dan monokultur sehingga produktivitasnya rendah. Pemberdayaan masyarakat di kawasan Greenbelt di kecamatan Sukasada pada program IbW tahun 2013 ini dilakukan dengan pencanangan program aksi pertanian-peternakan multikultur, sesuai dengan diskusi mendalam dengan masyarakat di desa Wanagiri. Ketahanan 
ekonomi masyarakat yang banyak bertumpu dari hasil ternak-tani disikapi dengan mengembangkan ternak multikultur,yakni ternak sapi sebagai penghasil income tahunan, ternak babi sebagai penghasil income enan bulan, dan ayam merupakan sumber penghasilan masyarakat bulanan. Hal yang sama juga pada aspek pertanian, dimana masyarakat di setiap demplot sebagai episntrum aktivitas pemberdayaan, dikapasitaskan untuk menanam tananman yang dapat memenuhi kebutuhan konsumtif jangka pendek sampai jangka panjang.

Model pertanian-peternakan terpadu merupakan aktivitas produktif pertanianpeternakan dalam satu siklus berantai, yakni pemanfaatan limbah tanaman pada budidaya tani untuk pakan ternak. Demikian juga sebaliknya budidaya ternak, limbah ternak dapat dimanfaatkan untuk pertanian. Sebagai langkah awal diintroduksikan penanaman rumput raja dan gamal di pematang petakan lahan petani untuk menambah penyediaan hijauan pakan ternak selain itu juga diperkenalkan perkandangan menetap, dan pengawetan pakan ternak. Selanjutnya juga diintroduksikan pemanfaatan air embung untuk pertanaman sayuran (bawang merah, semangka, kacang panjang dan bawang putih) yang memiliki nilai ekonomis tinggi.

Program aksi usaha produktif pertanian-peternakan-perikanan terpadu diawali introduksi teknologi pemanfaatan limbah tanaman untuk pakan ternak menjadi pupuk bio-organik, dilaksanakan pada tanggal 6 September 2013, dan tanggal 13 September 2013. Hasil pemberdayaan masyarakat yang terkabung kelompok tani (poktan) dalam usaha produktif pertanian multikultur dan peternakan ternak sapi/babi terpadu adalah (1) adanya peningkatan kompetensi bertani multikultur dalam intensifikasi budi daya ternak sapi/babi/ayamayam terpadu, menuju usaha produktif yang zero waste, (2) mendorong proses transformasi IPTEKS dalam pengolahan limbah ternak sapi/babi/unggas menjadi pupuk. Terkait dengan pengkapasitasan poktan di desa Wanagiri dalam produksi bioorganik dalam skala besar, maka dari hibah IbW Greenbelt Sukasada juga menghibahkan satu unit mesin produksi pupuk organik dengan kapasitas yang besar.

Terkait dengan upaya Bupati Buleleng dalam mendongkrak perkembangan wisata ke Bali utara, maka desa Ambengan, yang merupakan jalur lintasan wisata trans Bedugul-Singaraja-Gilimanuk dapat mengkreasi secara kreatif produk kerajinan tangan berupa tas, album, bingkai foto, berbahan baku limbah pisang dan dedauanan secara 
lebih optimal.Dalam rangka mendukung program pemerintah kabupaten Buleleng ini, maka IbW Greenbelt Sukasada melaksanakan pelatihan diversifikasi roduksi kreatif kerajinan di desa Ambengan untuk mengintensifikasi dan mengekstensifikasi produksi kerajinan tangan kelompok masyarakat desa Ambengan, pada tanggal 23 Agustus 2013. Sekaligus saat pelatihan ini dihibahkan peralatan produksi kerajinan, seperti: mesin cetak/press, pisau, gunting. cutter, kuas, alat semprot cat/pernis, amplas, lem, kertas HVS, kertas lapis, plastik cover, dan lain-lain.

Potensi wisata air terjun di desa Gigit merupakan aset desa yang dapat mendatangkan generate revenue bagi masyarakat Gigit. Pengelolaan wisata yang tradisional, penataan kawasan, dan managemen pemasaran yang konvensional belum mampu meningkatkan taraf pendapatan warga, apalagi dengan kompetensi bahasa asing dan literasi wisata yang rendah. Maka dari itu, dalam program IbW Greenbelt Sukasada tahun 2013 dilakukan edukasi dan penatan secara bertahap terhadap SDM dan keasrian objek wisata air terjun Gitgit, yakni : (1) Pelatihan English for Guiding untuk program rural agro-torurims bagi praktisi wisata di kawasan air terjun dari 25 Oktober 2013 sampai 3 November 2013, (2) Pembangunan secara bertahap gerbang welcome gate pada objek wisata air terjun Gigit.

\section{Penutup}

Dari paparan hasil pelaksanaan IbW Sukasada, maka dapat disimpulkan hal-hal sebagai berikut. Kegiatan IbW pada tahun 2013 telah mampu menghasilkan : (1) Rencana strategis (Renstra) dan pemetaan wilayah, (2) terwujudnya sentra pengolahan kelapa, (3) Terwujudnya demplot peternakan-pertanian ramah lingkungan (zero waste), (4) terwujudnya produk wisata rural-agrotourism culture, dan (5) publikasi ilmiah hasil program IbW pada jurnal lokal, nasional, dan internasional.

\section{DAFTAR PUSTAKA}

Anonim. 2012. RPJM Desa Ambengan. Kecamatan Sukasada. Kabupaten Buleleng:Bali Anonim. 2012. RPJM Desa Gitgit. Kecamatan Sukasada. Kabupaten Buleleng:Bali Anonim. 2012. RPJM Desa Wanagiri. Kecamatan Sukasada. Kabupaten Buleleng:Bali 
Anonim. 2012. RPJM Desa Pancasari. Kecamatan Sukasada. Kabupaten Buleleng:Bali

Anonin. 2010. Profil Kecamatan Sukasada, kabupaten Buleleng:Bali

BPS, 1998. Crisis Poverty and Human Development in Indonesia. BPS. UNDP, Jakarta

Emil Salim. 1980. Perencanaan Pembangunan dan Pemerataan Pendapatan. Jakarta Yayasan Idayu.

Ernan Rustiadi, Sunsun Saefulhakim Dyah R. Panuju. 2009. Perencanaan dan Pengembangan Wilayah. Crestpen Press dan Yayasan Obor Indonesia. Jakarta.

Irawan, P.B. dan Romdiati. H, 2000. The Impact of Economic Crisis on Povertyand its Implication for Development Strategies, Paper Presented at National Workshop on Food and Nutrition VII. LIPI, 29 Febuari - 2 Maret 2000, Jakarta

Kartasasmita, Ginandjar. 1995. Pemberdayaan Masyarakat: Sebuah Tinjauan Administrasi; Pidato Pengukuhan Jabatan Guru Besar dalam Ilmu Administrasi pada Fakultas Ilmu Administrasi Pemangunan Universitas Brawijaya; Malang. 1995.

Michael Sherraden. 2006. Aset untuk Orang Miskin: Perspektif Baru Usaha Pengentasan Kemiskinan. PT RajaGrafindo Persada. Jakarta.

Millind B Bhujbal. 2012. Agro-tourism A Specialized Rural Tourism: Innovative Product of Rural Market. International Journal of Bussiness \& Management Tomorrow. Vol. 2 No:1

Olivier Serrat. 2008. The Sustainable Livelihoods Approach. Asean Development Bank

Shadi Hamadeh. 2009. The Sustainable Livelihoods Approach (SLA) In Mena:A Bitter Sweet Experience. Environment and Sustainable Development Unit Faculty of Agricultural and Food Sciences American University of Beirut

Sumodiningrat, Gunawan,, 1999, Pemberdayaan Masyarakat Dan JPS, PT Gramedia,Jakarta 